\title{
ACKR2 Gene
}

National Cancer Institute

\section{Source}

National Cancer Institute. ACKR2 Gene. NCI Thesaurus. Code C21592.

This gene plays a role in in leukocyte circulation and pro-inflammatory responses;

however, a specific function has yet to be elucidated. 